\title{
Association between dietary nutrient intake and sarcopenia in older adults
}

\author{
Felicita Urzi', Sandra Potušek', Laura lacolina',2, Elena Bužan' \\ ' University of Primorska, Faculty of Mathematics, Natural Sciences and Information Technologies, Koper, Slovenia \\ 2 Aalborg University, Department of Chemistry and Bioscience, Fredrik Bajers Vej 7H, 9220 Aalborg, Denmark \\ felicita.urzi@upr.si
}

\section{Abstract}

Introduction: There is increasing interest in modifiable factors that may be effective in both the prevention and treatment of sarcopenia. Although there is a growing evidence of the importance of nutrition in the treatment of sarcopenia, studies examining the relationship between nutrient intake and sarcopenia in older adults are limited. The aim of this study was to examine the association between nutrient intake and sarcopenia in older adults. Methods: The case-control observational study included 115 older adults ( $\geq 65$ years), 26 of whom were classified as sarcopenic. Sarcopenia was assessed according to the European Working Group on Sarcopenia in Older People (EWGSOP) diagnostic criteria. Habitual dietary intake was assessed with the 3-day weighed dietary record over two weekdays and one weekend day. The weight of food intake in grams was converted into energy, macronutrient and micronutrient amounts using the online OPEN (Open Platform for Clinical Nutrition) dietary assessment tool. The mini nutritional assessment (MNA) was used to assess the nutritional status. Differences in nutrient intake and nutritional status between the sarcopenic and non-sarcopenic groups were evaluated. Risk factors were determined using logistic regression with sarcopenic status as the outcome. Results: Seven nutrients (n-3 fatty acid, vitamin D, vitamin K, vitamin $\mathrm{C}$, vitamin $\mathrm{B} 1$, vitamin $\mathrm{B} 7$, and vitamin $\mathrm{B} 9$ ) were all statistically significantly lower in the sarcopenic compared to the non-sarcopenic group $(\mathrm{p}<.05)$. An increased risk of sarcopenia $\left(\mathrm{R}_{2}=.756\right)$ was found in older adults with low dietary intakes of n-3 fatty acids. After accounting for possible covariates, the evidence for an association between n-3 fatty acid and sarcopenia is partially explained by age, body mass index, presence of diabetes mellitus, hypertension, and physical activity level. Discussion and conclusions: Sarcopenic older adults differed in terms of intake of seven nutrients compared with non-sarcopenic older adults. 


\begin{abstract}
Adequate intake in some of these nutrients have been repeatedly shown to be valuable in preserving muscle mass and protecting against normal decline in the elderly, both in randomized controlled trials and in cohort analyses. Given that nutrition may influence the development of sarcopenia, nutrition intervention may represent a feasible measure for preventing or postponing age-related decline in muscle mass and function.
\end{abstract}

\begin{abstract}
Keywords: nutrition, sarcopenia, n-3 fatty acid, vitamin D, nutritional assessment
\end{abstract}

\title{
Introduction
}

Sarcopenia is defined as the presence of low muscle strength, low muscle quantity/quality and low physical performance (Morley et al., 2011; Cruz-Jentoft et al., 2019). Today it is recognized as an age-related disease with ICD-10-CM (M62.84) code (Anker et al., 2016). The overall estimates of prevalence of sarcopenia in older adults worldwide is $10 \%$ (Shafiee et al., 2017), while it may be as high as 30\% in community-dwelling populations and even higher than $30 \%$ for populations in long-term care (Cruz-Jentoft et al., 2014). The consequences of having sarcopenia are reflected in loss of independence due to impaired physical performance, increased risk of mobility disorders, falls and fractures and impaired ability to perform activities of daily living, leading to nursing home admission, depression, hospitalization, and even death (Landi et al., 2013; Correa-de-Araujo and Hadley 2014; Cruz-Jentoft and Sayer 2019). In addition, its presence is associated with other comorbidities, such as osteoporosis, diabetes mellitus, insulin resistance, obesity, and chronic kidney disease, which have an important impact on the public health burden (Beaudart et al., 2014; Kim et al., 2014; Pacifico et al., 2020).

Multiple risk factors contribute to the aetiology of sarcopenia. Changes in muscle morphology, neurodegenerative process, anabolic and sex hormone production or sensitivity, protein balance, increased oxidative stress, inflammation and genetic predisposition are important risk factors (Roubenoff, 2003; Fulle et al., 2004; Can et al., 2016; Coen et al., 2019; Bauer, 2021; Priego et al., 2021). which leads to reduced mobility, fragility and loss of independence. This process called sarcopenia is secondary to several factors such as sedentary lifestyle, inadequate nutrition, chronic inflammatory state and neurological alterations. However, the endocrine changes associated with aging seem to be of special importance in the development of sarcopenia. On one hand, advancing age is associated with a decreased secretion of the main hormones that stimulate skeletal muscle mass and function (growth hormone, insulin-like growth factor 1 (IGF[sbnd]IAlong with these changes in older adults, decreased basal metabolic rate and increased dietary protein needs are also detected (Wilson and Morley, 2003; Bauer et al., 2013; Boirie, 2014). Besides these endogenous factors, inadequate nutrition and a sedentary lifestyle also contribute to the complex aetiology of sarcopenia (Rolland et al., 2008; Walrand et al., 2011; 
Volkert et al., 2018; Beaudart et al., 2019). Many of them are not modifiable since they are caused by progressive, irreversible processes contributing to reduced muscle mass and strength (Rolland et al., 2008; Cruz-Jentoft nad Sayer 2019). Therefore, there is rising interest in studies that point to the influence of modifiable factors such as nutrition and lifestyle, because these factors may be effective for both the prevention and treatment of sarcopenia. Proper nutrition is an important determinant of health and can contribute to protection against the negative impact of age-related changes of body composition and muscle quality decline (Volkert et al., 2018; Beaudart et al., 2019). Evidences shows significantly lower dietary nutrient intakes of at least 3-6 nutrients in sarcopenic comparing to non-sarcopenic older adults (ter Borg et al., 2016; Beaudart et al., 2019). Results of some studies have led to the proposition that $n-3$ fatty acid along with vitamin $\mathrm{D}$, protein intake and physical activity as a combined intervention could be effective in the management of sarcopenia (Boirie et al., 2014; $\mathrm{Wu}$ et al., 2020). Antioxidant nutrients (carotenoids, selenium and vitamins $\mathrm{E}$ and $\mathrm{C}$ ) intake have also been associated with sarcopenia (Lauretani et al., 2007; Chen et al., 2014; Welch et al., 2020).

Studies that evaluate the association between nutrient intake and sarcopenia in older adults is limited. To fill this gap, this study aims to evaluate the differences in nutrition intake among sarcopenic and non-sarcopenic older adults.

\section{Methods}

\section{Study design and participants}

This case-control observational study is set to identify nutritional factors that differ in sarcopenic and nonsarcopenic groups of older adults.

Study participants were older adults ( $\geq 65$ years) selected from our previous study (Urzi et al., 2017). The sample was composed of 115 participants, 26 of whom had sarcopenia; 75 older adults living in a nursing home and 40 free-living older adults (29\% of men; average age $77.7 \pm 10.3$ years). Sarcopenia was assessed according to the EWGSOP diagnostic criteria (Cruz-Jentoft et al., 2010). For details on health-related data, body composition measurements and sarcopenia assessment see our original publication (Urzi et al., 2017). We conducted our study in compliance with the principles of the Declaration of Helsinki. The study was approved by the Republic of Slovenia National Medical Ethics Committee (No. 0120-313/2015-6 KME 105/06/16).

\section{Dietary Intake and Malnutrition Assessment}

Habitual dietary intake was assessed with the 3-day weighed dietary record over two weekdays and on one weekend day. The weight of food intake in grams was converted into energy, macronutrient and micronutrient amounts using the online OPEN (Open Platform for Clinical Nutrition dietary assessment tool (http://www.opkp.si)). 
The mini nutritional assessment (MNA) was used to assess the nutritional status. Malnutrition indication scores ranged from 17 to 30 points. Participants were classified according to achieved scores as follows: from 24 to 30 points (normal nutritional status), from 17 to 23.5 points (at risk of malnutrition), and less than 17 points (malnourished) (Vellas et al., 1999).

\section{Statistical analysis}

Data were analysed using SPSS version 25 (SPSS Inc., Chicago, IL). For continuous variables, we calculated mean values, standard deviations, and medians. Categorical variables are expressed as numbers and percentages.

Normality in the distribution of variables was tested with the Shapiro-Wilk test. The homogeneity of variances was tested by Leven's test for equality of variances. For continuous variables, differences in participant's characteristics between those with and without sarcopenia were examined using the unpaired Student's t-test or Mann-Whitney U test. For categorical variables, comparisons between groups were made using the $\chi^{2}$-test. Risk factors were determined using logistic regression with sarcopenic status as the outcome. Initially, those dietary factors that were significantly different between groups were included in a multivariate model to determine the best predictor of sarcopenic status. Those factors that were significant at the $\mathrm{p}=.05$ level were included in the multivariate model, having taken into consideration possible covariates, to determine whether the dietary intake differences between the groups were related to sarcopenia. The following covariates were included for the evaluation of dietary intake: sex, age, body mass index, MNA malnutrition category, energy intake, diabetes mellitus, hypertension, heart disease, depression, chronic obstructive pulmonary disease (COPD) and physical activity level. All statistical tests were 2-sided. A p value lower than .05 was considered statistically significant.

\section{Results}

Baseline characteristics of study participants in relation to the presence of sarcopenia according to EWGSOP (Cruz-Jentoft et al., 2010) diagnostic criteria are presented in Table 1 and Table 2 . We found lower body mass index $(\mathrm{t}(113)=$ 2.839, $\mathrm{p}=.005)$, skeletal muscle index $(\mathrm{U}=439, \mathrm{z}=-4.801, \mathrm{p}=<.001)$, gait speed $(\mathrm{U}=440, \mathrm{z}=-4.794, \mathrm{p}<.001)$, and grip strength $(\mathrm{U}=319, \mathrm{z}=-5.605, \mathrm{p}<.001)$ in the sarcopenic group. The sarcopenic participants also reported a lower level of physical activity than the nonsarcopenic older adults $(U=761, z=-2.792$, $\mathrm{p}=.005)$, and had significantly higher rates of diabetes mellitus $\left(\chi^{2}(1)=5.25, \mathrm{p}\right.$ $=.022)$, and hypertension $\left(\chi^{2}(1)=5.59, \mathrm{p}=.018\right)$. The risk of malnutrition was higher $\left(\chi^{2}(1)=10.45, \mathrm{p}=.001\right)$ in the sarcopenic $(42.3 \%)$ comparing to the nonsarcopenic group (13.5\%). None of the participants were malnourished. 
Table 1: Characteristic of study participants in relation to the presence of sarcopenia by EWGSOP diagnostic criteria

\begin{tabular}{lccc}
\multicolumn{1}{c}{ Variables } & $\begin{array}{c}\text { Non sarcopenic } \\
(n=89)\end{array}$ & $\begin{array}{c}\text { Sarcopenic } \\
(n=26)\end{array}$ & T-test / Mann-Whitney \\
\hline Mge (years) & $75.2(10.0)$ & $\mathrm{M}(\mathrm{SD})$ & $\mathrm{p}$-values \\
\hline Body height $(\mathrm{cm})$ & $163.0(8.7)$ & $86.2(5.98)$ & $<.001$ \\
\hline Body mass $(\mathrm{kg})$ & $74.0(13.0)$ & $159.3(8.9)$ & .063 \\
\hline $\begin{array}{l}\text { Body mass index }(\mathrm{kg} / \\
\text { m2) }\end{array}$ & $28.1(5.5)$ & $62.8(11.6)$ & .005 \\
\hline $\begin{array}{l}\text { Skeletal muscle index } \\
(\mathrm{kg} / \mathrm{m} 2)\end{array}$ & $7.79(1.22)$ & $24.7(3.8)$ & $<.001$ \\
\hline Gait speed $(\mathrm{m} / \mathrm{s})$ & $0.92(0.43)$ & $6.59(1.02)$ & $<.001$ \\
\hline Grip strength $(\mathrm{kg})$ & $28.0(9.34)$ & $0.46(0.18)$ & $<.001$ \\
\hline Physical activity level & $1.38(0.13)$ & $16.6(6.07)$ & .005 \\
\hline
\end{tabular}

Table 2: Nutritional and health status of study participants in relation to the presence of sarcopenia by EWGSOP diagnostic criteria

\begin{tabular}{|c|c|c|c|}
\hline Variables & Non sarcopenic & Sarcopenic & $\chi^{2}$-test \\
\hline & $\mathrm{n}(\%)$ & $\mathrm{n}(\%)$ & p-values \\
\hline \multicolumn{4}{|l|}{$\begin{array}{l}\text { Mini Nutritional Assess- } \\
\text { ment }\end{array}$} \\
\hline $\begin{array}{l}\text { Normal nutrition- } \\
\text { al status }\end{array}$ & $77(86.5)$ & $15(57.7)$ & .001 \\
\hline At risk of malnutrition & $12(13.5)$ & $11(42.3)$ & \\
\hline Malnourished & o (o) & $\mathrm{o}(\mathrm{o})$ & \\
\hline $\begin{array}{l}\text { Chronic obstructive pul- } \\
\text { monary disease }\end{array}$ & $3(3.4)$ & $1(3.8)$ & l \\
\hline Type 2 diabetes & $12(13.5)$ & $8(30.8)$ & .022 \\
\hline Hypertension & $29(32.6)$ & $14(53.8)$ & .018 \\
\hline Heart disease & $10(11.2)$ & $4(15.4)$ & .463 \\
\hline Other diseases & $35(39.3)$ & $13(50.0)$ & .365 \\
\hline
\end{tabular}

Note. EWGSOP = European Working Group on Sarcopenia in Older People. Sarcopenia: low muscle mass, cut off point $\leq 8.87 \mathrm{~kg} / \mathrm{m}_{2}$ (in men) and $\leq 6.42 \mathrm{~kg} / \mathrm{m} 2$ (in women) and low muscle strength (men <3o kg; women $<20 \mathrm{~kg}$ ) and/or low physical performance (gait speed $<0.8 \mathrm{~m} / \mathrm{s}$ ).

Comparison of dietary intake between sarcopenic and nonsarcopenic older individuals

The dietary intake of the sarcopenic and nonsarcopenic groups are shown in Table 2. Energy intake does not differ between the groups, but when expressed as energy intake per kg of body mass per day, the sarcopenic group shows higher values compared to the non-sarcopenic group (24.9 vs. $28.8 \mathrm{~g} / \mathrm{kg}$ per day; $U=1689, \mathrm{z}=3.544, \mathrm{p}<.001)$. The sarcopenic participants also have a higher protein intake (1.13 vs. $0.95 \mathrm{~g} / \mathrm{kg}$ bw/d; $\mathrm{t}(113)=-3.592, \mathrm{p}<.001)$. Compared with the PROT-AGE recommendations for dietary protein intake (Bauer et al., 2013), the proportion of older adults with dietary protein intake lower than 1.0 
$/ \mathrm{kg}$ bw/d were $19 \%$ and $57 \%$ for sarcopenic and non-sarcopenic older adults, respectively. Intakes lower than $1.2 \mathrm{~g} / \mathrm{kg}$ bw/d amounted to $69 \%$ for the sarcopenic and $89 \%$ for the non-sarcopenic group. Greater daily protein intake in the sarcopenic group was not reflected in the differences in branch chain amino acid (BCAA) $(\mathrm{p}=.981)$ or leucine $(\mathrm{p}=.931)$ intake between the two groups.

There were no significant differences in daily intake of carbohydrate $(\mathrm{p}=$ $.229)$, fat ( $\mathrm{p}=.583)$, and saturated fatty acid ( $\mathrm{p} \geq .24)$. Other nutrients like $\mathrm{n}-3$ fatty acid $(\mathrm{U}=544, \mathrm{z}=-4.099, \mathrm{p}<.001)$, vitamin $\mathrm{D}(\mathrm{U}=750, \mathrm{z}=-2.721, \mathrm{p}=.007)$, vita$\min \mathrm{K}(\mathrm{U}=691, \mathrm{z}=-3.116, \mathrm{p}=.002)$, vitamin $\mathrm{C}(\mathrm{U}=843, \mathrm{z}=-2.099, \mathrm{p}=.036)$, vi$\operatorname{tamin} \mathrm{B}_{1}(\mathrm{U}=69 \mathrm{o}, \mathrm{z}=-3.112, \mathrm{p}=.002)$, vitamin $\mathrm{B}_{7}(\mathrm{U}=68 \mathrm{o}, \mathrm{z}=-3.189, \mathrm{p}=.001)$, and vitamin $\mathrm{B} 9(\mathrm{U}=589, \mathrm{z}=-3.798, \mathrm{p}<.001)$ were all lower in the sarcopenic compared to the non-sarcopenic group. Intakes of all other nutrients did not differ between the two groups $(\mathrm{p} \geq .062)$. The proportion of individuals whose usual intake of n-3 fatty acid was below the RDA (Reference dietary values DACH, 2004) was $100 \%$ in the sarcopenic group and $83.1 \%$ in the nonsarcopenic group. Vitamin D intake was lower than the RDA in both the sarcopenic and nonsarcopenic group (in $100 \%$ and $87.6 \%$ of individuals, respectively). Folic acid intake was substantially lower than the RDA in the sarcopenic and nonsarcopenic group (in $100 \%$ and $89.9 \%$ of individuals, respectively). Thiamine intake was also lower than the RDA in both the sarcopenic and nonsarcopenic group (92.3\% and $53.9 \%$, respectively). Dietary supplement users in nonsarcopenic group was $9 \%$ (supplement: $9 \%$ vitamin D, $4 \%$ n-3 fatty acid, $2 \%$ vitamin C and $1 \%$ vitamin B), while none of the sarcopenic participants used supplements.

Table 3: Average daily dietary intakes by non-sarcopenic and sarcopenic older adults

\begin{tabular}{lccc}
\multicolumn{1}{c}{ Characteristic } & $\begin{array}{c}\text { Non sarcopenic } \\
(n=89)\end{array}$ & $\begin{array}{c}\text { Sarcopenic } \\
(n=26)\end{array}$ & T-test / Mann-Whitney \\
\hline Energy $(\mathrm{kcal})$ & $1809(375)$ & $\mathrm{M}(\mathrm{SD})$ & .392 \\
\hline $\begin{array}{l}\text { Energy }(\mathrm{kcal} / \mathrm{kg} \mathrm{BM} \\
\text { / day) }\end{array}$ & $24.9(6.03)$ & $1786(329)$ & $<.001$ \\
\hline Protein $(\mathrm{g} / \mathrm{kg} \mathrm{BM} / \mathrm{day})$ & $0.95(0.24)$ & $28.8(4.75)$ & $<.001$ \\
\hline Carbohydrates $(\mathrm{g})$ & $221(55.4)$ & $1.13(0.18)$ & .229 \\
\hline $\begin{array}{l}\text { \% Energy from Carbo- } \\
\text { hydrates }\end{array}$ & $48.9(6.92)$ & $211(50.5)$ & .172 \\
\hline Fat $(\mathrm{g})$ & $70.0(19.8)$ & $47.2(4.91)$ & .583 \\
\hline \multicolumn{1}{c}{$\%$ Energy from Fat } & $34.7(6.51)$ & $72.3(15.2)$ & .205 \\
\hline BCAA $(\mathrm{g})$ & $9.81(2.37)$ & $36.5(4.92)$ & .981 \\
\hline Leucine $(\mathrm{g})$ & $4.05(0.95)$ & $9.80(1.63)$ & .931 \\
\hline Palmitic acid $(\mathrm{g})$ & $10.5(3.20)$ & $4.03(0.67)$ & .249 \\
\hline Stearic acid $(\mathrm{g})$ & $4.57(1.55)$ & $11.2(2.20)$ & .489 \\
\hline $\mathrm{n}-3$ fatty acid $(\mathrm{g})$ & $1.04(0.76)$ & $4.74(0.98)$ & $<.001$ \\
\hline $\mathrm{n}-6$ fatty acid $(\mathrm{g})$ & $8.73(4.33)$ & $0.57(0.14)$ & .904 \\
\hline Vitamin D $(\mu \mathrm{g})$ & $4.40(6.59)$ & $8.36(3.07)$ & .007 \\
\hline Vitamin E $(\mathrm{mg})$ & $10.1(2.98)$ & $1.44(0.38)$ & .062 \\
\hline
\end{tabular}




\begin{tabular}{|c|c|c|c|}
\hline Characteristic & $\begin{array}{c}\text { Non sarcopenic } \\
\quad(n=89)\end{array}$ & $\begin{array}{l}\text { Sarcopenic } \\
\quad(n=26)\end{array}$ & T-test / Mann-Whitney \\
\hline Vitamin K $(\mu \mathrm{g})$ & $138(112)$ & $77.7(27.2)$ & .002 \\
\hline Vitamin C (mg) & $76.6(39.8)$ & $57.7(18.5)$ & .036 \\
\hline Vitamin $\mathrm{B}_{1}$ (mg) & $0.97(0.33)$ & $0.76(0.11)$ & .002 \\
\hline Vitamin B2 (mg) & $1.27(0.31)$ & $1.24(0.23)$ & .714 \\
\hline Vitamin B5 (mg) & $3.91(0.97)$ & $3.51(0.63)$ & .072 \\
\hline Vitamin B6 (mg) & $1.34(0.44)$ & $1.15(0.19)$ & .091 \\
\hline Vitamin B7 $(\mu \mathrm{g})$ & $20.1(11.2)$ & $12.8(5.03)$ & .001 \\
\hline Vitamin B9 (mg) & $0.21(0.08)$ & $0.15(0.02)$ & $<.001$ \\
\hline Vitamin B12 $(\mu \mathrm{g})$ & $2.89(1.29)$ & $2.55(0.54)$ & .349 \\
\hline Potassium (g) & $2.54(0.58)$ & $2.31(0.39)$ & .131 \\
\hline Calcium (g) & $0.74(0.22)$ & $0.81(0.18)$ & .161 \\
\hline Magnesium (g) & $0.32(0.12)$ & $0.27(0.04)$ & .166 \\
\hline Phosphorus (g) & $1.02(0.25)$ & $0.99(0.20)$ & .570 \\
\hline Iron $(\mathrm{g})$ & $13.1(3.68)$ & $11.8(2.12)$ & .088 \\
\hline Copper (mg) & $1.37(0.40)$ & $1.30(0.24)$ & .290 \\
\hline Selenium $(\mu \mathrm{g})$ & $51.0(16.6)$ & $45.1(12.9)$ & .175 \\
\hline Zinc (mg) & $7.90(1.99)$ & $7.65(0.29)$ & .784 \\
\hline
\end{tabular}

\begin{tabular}{|c|c|c|c|}
\hline & & Model I & \\
\hline Factor & $\beta$-value & p-value & Odds ratio $(95 \% \mathrm{CI})$ \\
\hline n-3 fatty acid (g) & -3.232 & .035 & $0.039(0.002-0.793)$ \\
\hline Vitamin D $(\mu \mathrm{g})$ & -0.059 & .786 & $0.943(0.617-1.441)$ \\
\hline Vitamin K $(\mu \mathrm{g})$ & -0.006 & .386 & $0.994(0.981-1.007)$ \\
\hline Vitamin C (mg) & 0.010 & .529 & $1.010(0.980-1.040)$ \\
\hline Vitamin $B_{1}(\mu \mathrm{g})$ & -1.726 & .450 & $0.178(0.002-15.71)$ \\
\hline Vitamin $B_{7}(\mu \mathrm{g})$ & -0.007 & .895 & $0.993(0.897-1.100)$ \\
\hline Vitamin $B_{9}(\mu \mathrm{g})$ & -0.013 & .377 & $0.987(0.959-1.016)$ \\
\hline
\end{tabular}


In Table 5 the model after controlling for sex, age, body mass index, MNA malnutrition category, energy intake, diabetes mellitus, hypertension, heart disease, depression, COPD and physical activity level is shown. An increased risk of sarcopenia $\left(\mathrm{R}_{2}=0.756\right)$ was found in older adults with a low dietary intake of n-3 fatty acid (OR 0.002, 95\% CI 0.00o-0.461, p = .025), body mass in$\operatorname{dex}(\mathrm{OR}$ 0.611, 95\% CI 0.438-0.853, p = .004), physical activity level (OR o.001, 95\% CI 0.000-0.873, $\mathrm{p}=.048$ ), with the presence of diabetes mellitus (OR o.0o6, 95\% CI 0.000-0.170, $\mathrm{p}=.003$ ), hypertension (OR 0.063, 95\% CI 0.005-0.768, p $=.030$ ), and were older (OR 1.172, 95\% CI 1.016-1.352, $\mathrm{p}=.030)$. Sex, MNA malnutrition category, energy intake, heart disease, depression, and COPD did not achieve statistical significance in this model ( $\mathrm{p} \geq .092)$.

\section{Table 5: Regression coefficients and odds ratios (and 95\% CIs) for risk factors associated with sarcopenia}

\begin{tabular}{lccc} 
& & Model II & \\
\hline \multicolumn{1}{c}{ Factor } & $\beta$-value & -value & Odds ratio (95\% CI) \\
\hline $\mathrm{n}-3$ fatty acid $(\mathrm{g})$ & -6.226 & .025 & $0.002(0.000-0.461)$ \\
\hline Age (years) & 0.159 & .030 & $1.172(1.016-1.352)$ \\
\hline Physical activity level & -12.527 & .048 & $0.000(0.000-0.873)$ \\
\hline $\begin{array}{l}\text { Body mass index (kg/ } \\
\text { m2) }\end{array}$ & -0.492 & .004 & $0.611(0.438-0.853)$ \\
\hline $\begin{array}{l}\text { Diabetes mellitus (pres- } \\
\text { ence) }\end{array}$ & -5.039 & .003 & $0.006(0.000-0.170)$ \\
\hline Hypertension (presence) & -2.768 & .030 & $0.063(0.005-0.768)$ \\
\hline
\end{tabular}

Note. Binary logistic analyses were used to estimate the odds ratio (OR) and $95 \%$ confidence interval (CI) of factors related to sarcopenia. Adjusted model for sex, age, body mass index, MNA malnutrition categories, energy intake, diabetes mellitus, hypertension, heart disease, depression, COPD and physical activity level.

\section{Discussion}

Deficiencies in both macronutrients and micronutrients can be considered as a risk factor for sarcopenia, because such deficiencies can accelerate age-dependent changes in body composition, involving the loss of muscle mass, strength and function (Walrand et al., 2011; Volkert et al., 2018; Beaudart et al., 2019). We aimed to investigated nutritional factors that may be associated with the aetiology of sarcopenia by comparing the habitual dietary intake of the sarcopenic and nonsarcopenic groups of older adults.

The findings show that older adults in the sarcopenic group were more likely at risk of malnutrition (42.3\%) than those in the nonsarcopenic group (13.5\%) and demonstrate a higher rate of co-morbidities such as diabetes mellitus and hypertension. According to the MNA, although none of the participants was malnourished, $20 \%$ were at risk of malnutrition. The proportion of older adults who are malnourished or at risk of malnutrition vary depending on the cohort in the study. We found that the proportion of participants at risk of malnutrition was as high as $42.5 \%$ in the nursing homes (Lardiés-Sánchez et 
al., 2017), or 9\% among community-dwelling older adults (ter Borg et al., 2016). Although we observed significant differences in the MNA malnutrition category between the sarcopenic and nonsarcopenic group, as in other studies (ter Borg et al., 2016; Lardiés-Sánchez et al., 2017), it was not identified as a covariate for some of the observed nutrient intake differences.

The energy intake of the present population was 7.1-8.6MJ (1696.9 kcal $2055.4 \mathrm{kcal}$ ) including intake of carbohydrate 48-49 En\%, protein 15-16 En\%, and fat 33-35 En\%. These results are in line with the intake data of older adults from systematic literature review (ter Borg et al., 2015), and other studies (van Rossum et al., 2011; ter Borg et al., 2016) that indicates suboptimal macronutrient intakes among older adults. We did not observe significant differences in energy intake between the sarcopenic and nonsarcopenic group, similar to the results of Maastricht Sarcopenia Study (ter Borg et al., 2016).

Even though the greater proportion of the sarcopenic participants meet the lower range of evidence-based recommendations for optimal dietary protein intake of $1.0 \mathrm{~g} / \mathrm{kg}$ bw/d (Bauer et al., 2013), the inadequate nutrition pattern of this group was reflected in the insufficient daily amount of seven nutrients ( $\mathrm{n}-3$ fatty acid, vitamins D, K, C, thiamine, biotin and folic acid). Besides, the evidence shows that protein intake alone is not sufficient to preserve muscle quality but it is rather an interplay of group of nutrients that contribute to the prevention of sarcopenia (Verlaan et al., 2018). The literature suggests that adequate intake of proteins ( $1.2 \mathrm{~g} / \mathrm{kg}$ bw/d), n-3 fatty acids, and vitamin D, combined with physical exercise, forms part of an integrated management of sarcopenia (Boirie et al., 2014; Wu et al., 2020).

A significantly lower intake of thiamine, biotin, and folate $(21 \%, 36 \%$, and $28 \%$, respectively) was observed in our sarcopenic group compared to the nonsarcopenic group. The literature review (ter Borg et al., 2015; ter Borg et al., 2016; Beaudart et al., 2019) identified six nutrients (thiamin, riboflavin, vitamin D, $\mathrm{Ca}, \mathrm{Mg}$ and $\mathrm{Se}$ ) of potential concern as a result of a high prevalence of micronutrient inadequacy in diets among older adults in Europe. Furthermore, a possible link between vitamins B and the aetiology of sarcopenia was proposed (ter Borg et al., 2016; Bulut et al., 2017; Aytekin, 2018). The mechanisms are mainly related to the reduced activity of vitamin B1 dependent enzymes in mitochondria, and folate deficiency with hyperhomocysteinaemia. Deficiencies in these vitamins can include impairments in oxidative metabolism, and mitochondrial function, leading to inflammatory responses associated with increased production of reactive oxygen species and excitotoxicity, which causes muscle protein degradation (ter Borg et al., 2016; Aytekin, 2018).

The comparison of vitamin D intake between the groups showed a significantly lower vitamin D intake in the sarcopenic group of $67 \%$. Furthermore, none of the sarcopenic participants were supplemented with vitamin D. Supportive evidence shows the clinical relevance of vitamin D supplementation in the treatment and prevention of sarcopenia (Cangussu et al., 2015; Verlaan et al., 2018). 
We observed a 45\% lower n-3 fatty acids intake in the sarcopenic group compared to the nonsarcopenic group. The findings of our study show that a higher dietary intake of n-3 fatty acid in the nonsarcopenic group was associated with a significantly reduced risk of sarcopenia. The analyses considered possible covariates and indicated that the association between n-3 fatty acid and sarcopenia is partially explained by age, body mass index, presence of diabetes mellitus, hypertension, and physical activity level.

Various randomized controlled trials and cohort analysis shows a significant role of the dietary intake of n-3 fatty acids in preventing sarcopenia and muscle loss (Ganapathy and Nieves, 2020). Besides, it was shown that n-3 fatty acid supplementation directly stimulates muscle protein synthesis in older adults and may be effective for muscle mass gain (Smith et al., 2011). Some previous studies have discovered that the prevalence of chronic disease is interrelated with systemic chronic low-grade inflammation, which contributes to the loss of muscle mass, strength and function through several cytokine signalling pathways (Kim et al., 2014; Dalle et al., 2017). It was suggested that nutrients like n-3 fatty acids might have the potential of preventing and reducing numerous chronic conditions caused by inflammatory factors by decreasing the level of inflammatory cytokines, and prevent the loss of muscle mass, strength and function associated with age-related sarcopenia (Smith, 2016; Buoite et al., 2018).

Certain limitations must be taken into consideration. Based on the cross-sectional design of the study, no conclusion can be made on the cause-effect relationship between sarcopenia and nutrient factors. Therefore, research along with longitudinal design and controlled bias would be useful in providing further clarification on the effects of the differences in nutrient intake regarding the risk of sarcopenia.

\section{Conclusions}

Musculoskeletal health is important for the functionality and independence of older adults, and we showed that some nutrients as well as dietary patterns offer protective effects against age-related declines in muscle mass and function.

The present results suggest that sarcopenic older adults have important dietary deficiencies in n-3 fatty acids, vitamin D, vitamin $C$ and some vitamin B. The inadequate intake of these nutrients could be viewed as a risk factor for sarcopenia, although prospective studies are needed to confirm these findings.

\section{References}

ANKER, S.-D., MORLEY, J.-E., and HAEHLING, S., 2016. Welcome to the ICD-10 code for sarcopenia. Journal of Cachexia, Sarcopenia and Muscle, vol. 7, no. 5, p. 512-514.

AYTEKIN, N., MILEVA, K. N., and CUNLIFFE, A. D., 2018. Selected B vitamins and their possible link to the aetiology of age-related sarcopenia: 
relevance of UK dietary recommendations. Nutrition research reviews, vol. 31, no. 2, pp 204-224.

BAUER, J., BIOLO, G., CEDERHOLM, T., CESARI, M., CRUZ-JENTOFT, A.-J., MORLEY, J.-E., PHILLIPS, S., SIEBER, C., STEHLE, P., TETA, D., VISVANATHAN, R., VOLPI, E. and BOIRIE, Y., 2013. Evidence-Based Recommendations for Optimal Dietary Protein Intake in Older People: A Position Paper From the PROT-AGE Study Group. Journal of the American Medical Directors Association, vol. 14, no. 8, pp. 542-559.

BAUER, J.-M., 2021. Muscle Function and Sarcopenia: Clinical Implications of Recent Research. Journal of the American Medical Directors Association, vol. 22, no. 4, pp. 725-727.

BEAUDART, C., LOCQUET, M., TOUVIER, M., REGINSTER, J.-Y. and BRUYĖRE, O., 2019. Association between dietary nutrient intake and sarcopenia in the SarcoPhAge study. Aging Clinical and Experimental Research, vol. 31, no. 6, pp. 815-824.

BEAUDART, C., RIZZOLI, R., BRUYĖRE, O., REGINSTER, J.-Y. and BIVER, E., 2014. Sarcopenia: burden and challenges for public health. Archives of public health, vol. 72 , no. 1, pp. 45.

BEAUDART, C., SANCHEZ-RODRIGUEZ, D., LOCQUET, M., REGINSTER, J.-Y., LENGELÉ, L. and BRUYĖRE, O., 2019. Malnutrition as a Strong Predictor of the Onset of Sarcopenia. Nutrients, vol. 11, no. 12, pp. 2883.

BOIRIE, Y., MORIO, B., CAUMON, E. and CANO, N.-J., 2014. Nutrition and protein energy homeostasis in elderly. Mechanisms of Ageing and Development, vol. 136, pp.76-84.

BULUT, E.-A., SOYSAL, P., AYDIN, A.-E., DOKUZLAR, O., KOCYIGIT, S.-E. and ISIK, A.-T., 2017. Vitamin B12 deficiency might be related to sarcopenia in older adults. Experimental gerontology, vol. 95, pp.136-140.

BUOITE S.-A., GORTAN CAPPELLARI, G., BARAZZONI, R. and ZANETTI, M., 2018. Update on the impact of omega 3 fatty acids on inflammation, insulin resistance and sarcopenia: A review. International journal of molecular sciences, vol. 19, no. 1, pp. 218.

CAN, B., KARA, O., KIZILARSLANOGLU, M.-C., ARIK, G., AYCICEK, G.-S., SUMER, F., CIVELEK, R., DEMIRTAS, C. and ULGER, Z., 2016. Serum markers of inflammation and oxidative stress in sarcopenia. Aging Clinical and Experimental Research, vol. 29, no. 4, p. 745-752.

CANGUSSU, L.-M., NAHAS-NETO, J., ORSATTI, C.-L., BUELONI-DIAS, F.-N. and NAHAS, E.-A.-P., 2015. Effect of vitamin D supplementation alone on muscle function in postmenopausal women: a randomized, double-blind, placebo-controlled clinical trial. Osteoporosis International, vol. 26, no. 10, pp.2413-2421.

CHEN, Y.-L., YANG, K.-C., CHANG, H.-H., LEE, L.-T., LU, C.-W. and HUANG, K.-C., 2014. Low Serum Selenium Level Is Associated with Low 
Muscle Mass in the Community-Dwelling Elderly. Journal of the American Medical Directors Association, vol. 15, no. 11, pp.807-811.

COEN, P.-M., MUSCI, R.-V., HINKLEY, J.-M. and MILLER, B.-F., 2019. Mitochondria as a Target for Mitigating Sarcopenia. Frontiers in Physiology, [online]. [viewed 23 August 2021]. Available from: https://www.frontiersin.org/articles/10.3389/fphys.2018.01883/full

CORREA-DE-ARAUJO, R. and HADLEY, E., 2014. Skeletal Muscle Function Deficit: A New Terminology to Embrace the Evolving Concepts of Sarcopenia and Age-Related Muscle Dysfunction. The Journals of Gerontology Series A: Biological Sciences and Medical Sciences, vol. 69, no. 5, pp. 591-594.

CRUZ-JENTOFT, A.-J., BAEYENS, J.-P., BAUER, J.-M., BOIRIE, Y., CEDERHOLM, T., LANDI, F., MARTIN, F.-C., MICHEL, J.-P., ROLLAND, Y., SCHNEIDER, S.-M., TOPINKOVA, E., VANDEWOUDE, M. and ZAMBONI, M. Sarcopenia: European consensus on definition and diagnosis: Report of the European Working Group on Sarcopenia in Older People. Age and Ageing, vol. 39, no. 4, pp. 412-423.

CRUZ-JENTOFT, A.-J., LANDI, F., SCHNEIDER, S.-M., ZUNIGA, C., ARAI, H., BOIRIE, Y., CHEN, L.-K., FIELDING, R.-A., MARTIN, F.-C., MICHEL, J.-P., SIEBER, C., STOUT, J.-R., STUDENSKI, S.-A., VELLAS, B., WOO, J., ZAMBONI, M. and CEDERHOLM, T., 2014. Prevalence of and interventions for sarcopenia in ageing adults: a systematic review. Report of the International Sarcopenia Initiative (EWGSOP and IWGS). Age and Ageing, vol. 43, no. 6, pp. 748-759.

CRUZ-JENTOFT, A.-J. and SAYER, A.-A., 2019. Sarcopenia. The Lancet, vol. 393, no. 10191, pp. 2636-2646.

CRUZ-JENTOFT, A.-J, BAHAT, G., BAUER, J., BOIRIE, Y., BRUYĖRE, O., CEDERHOLM, T., COOPER, C., LANDI, F., ROLLAND, Y., SAYER, A.-A., SCHNEIDER, S.-M, SIEBER, C.-C, TOPINKOVA, E., VANDEWOUDE, M., VISSER, M., ZAMBONI, M., BAUTMANS, I., BAEYENS, J.-P., CESARI, M., CHERUBINI, A., KANIS, J., MAGGIO, M., MARTIN, F., MICHEL, J.-P., PITKALA, K., REGINSTER, J.-Y., RIZZOLI, R., SÁNCHEZ-RODRÍGUEZ, D. and SCHOLS, J., 2019. Sarcopenia: Revised European consensus on definition and diagnosis. Age and ageing, vol. 48, no. 1, pp.16-31.

DALLE, Sebastiaan, ROSSMEISLOVA, Lenka and KOPPO, Katrien, 2017. The role of inflammation in age-related sarcopenia. Frontiers in physiology, [online]. [viewed 23 August 2021]. Available from: https://www.frontiersin.org/articles/10.3389/fphys.2017.01045/full

FUlle, S., PROTASI, F., DI TANO, G., PIETRANGELO, T., BELTRAMIN, A., BONCOMPAGNI, S., VECCHIET, L. and FANÒ, G., 2004. The contribution of reactive oxygen species to sarcopenia and muscle ageing. Experimental gerontology, vol. 39, no. 1, pp. 17-24. 
Ganapathy, A. and Nieves, J.-W., 2020. Nutrition and sarcopenia-What do we know?. Nutrients, vol. 12, no. 6, pp. 1755.

KIM, J.-E., LEE, Y.-H., HUH, J.-H., KANG, D.-R., RHEE, Y. and LIM, S.-K., 2014. Early-stage chronic kidney disease, insulin resistance, and osteoporosis as risk factors of sarcopenia in aged population: The Fourth Korea National Health and Nutrition Examination Survey (KNHANES IV), 2008-2009. Osteoporosis International, vol. 25, no. 9, pp. 2189-2198.

LANDI, F., CRUZ-JENTOFT, A.-J., LIPEROTI, R., RUSSO, A., GIOVANNINI, S., TOSATO, M., CAPOLUONGO, E., BERNABEI, R. and ONDER, G., 2013. Sarcopenia and mortality risk in frail older persons aged 80 years and older: results from ilSIRENTE study. Age and Ageing, vol. 42, no. 2, pp. 203-209.

LARDIÉS-SÁNCHEZ, B., SANZ-PARÍS, A., PÉREZ-NOGUERAS, J., SERRANO-OLIVER, A., TORRES-ANORO, M.-E. and CRUZ-JENTOFT, A.-J., 2017. Influence of nutritional status in the diagnosis of sarcopenia in nursing home residents. Nutrition, vol. 41, pp.51-57.

LAURETANI, F., SEMBA, R.-D, BANDINELLI, S., RAY, A.-L, GURALNIK, J.-M and FERRUCCI, L., 2007. Association of low plasma selenium concentrations with poor muscle strength in older community-dwelling adults: the InCHIANTI Study. The American Journal of Clinical Nutrition, vol. 86, no. 2, pp. 347-352.

MORLEY, J.-E, ABBATECOLA, A.-M., ARGILES, J.-M, BARACOS, V., BAUER, J., BHASIN, S., CEDERHOLM, T., STEWART COATS, A.-J., CUMMINGS, S.-R, EVANS, W.-J, FEARON, K., FERRUCCI, L., FIELDING, R.-A, GURALNIK, J.-M, HARRIS, T.-B, INUI, A., KALANTAR-ZADEH, K., KIRWAN, B.-A., MANTOVANI, G., MUSCARITOLI, M., NEWMAN, A.-B, ROSSI-FANELLI, F., ROSANO, G.-M.C., ROUBENOFF, R., SCHAMBELAN, M., SOKOL, G.-H, STORER, T.-W, VELLAS, B., VON HAEHLING, S., YEH, S.-S. and ANKER, S.-D, 2011. Sarcopenia With Limited Mobility: An International Consensus. Journal of the American Medical Directors Association, vol. 12, no. 6, pp. 403-409.

Open Platform for Clinical Nutrition, OPEN, http://opkp.si/en, Ljubljana, Slovenia.

PACIFICO, J., GEERLINGS, M.-A., REIJNIERSE, E.-M., PHASSOULIOTIS, C., LIM, W.-K. AND MAIER, A.-B., 2020. Prevalence of sarcopenia as a comorbid disease: A systematic review and meta-analysis. Experimental gerontology, vol. 131, pp. 110801.

PRIEGO, T., MARTÍN, A.-I., GONZÁLEZ-HEDSTRÖM, D., GRANADO, M., LÓPEZ-CALDERÓN, A. and CARDALINI, D., 2021. Role of hormones in sarcopenia. Vitamins and Hormones, vol. 115, pp. 535-570.

Reference dietary values (DACH), German Nutrition Society (DGE), Austrian Nutrition Society (OGE), Swiss Society for Nutrition Research (SGE), Swiss Nutrition Association (SVE), Ministry of Health (2004), Ljubljana. 
ROLLAND, Y, CZERWINSKI, S, ABELLAN VAN KAN, G, MORLEY, J E, CESARI, M, ONDER, G, WOO, J, BAUMGARTNER, R, PILLARD, F, BOIRIE, Y, CHUMLEA, W M C and VELLAS, B, 2008. Sarcopenia: its assessment, etiology, pathogenesis, consequences and future perspectives. The journal of nutrition, health and aging, vol. 12, no. 7, pp. 433-50.

ROUBENOFF, R., 2003. Sarcopenia: Effects on Body Composition and Function. The Journals of Gerontology Series A: Biological Sciences and Medical Sciences, vol. 58, no. 11, pp. M1012-M1017.

SHAFIEE, G., KESHTKAR, A., SOLTANI, A., AHADI, Z., LARIJANI, B. and HESHMAT, R., 2017. Prevalence of sarcopenia in the world: a systematic review and meta- analysis of general population studies. Journal of Diabetes and Metabolic Disorders, vol. 16, no. 1, pp. 21.

SMITH, G.-I., 2016. The Effects of Dietary Omega-3s on Muscle Composition and Quality in Older Adults. Current Nutrition Reports, vol. 5, no. 2, pp.99-105.

SMITH, G.-I, ATHERTON, P., REED, D.-N, MOHAMMED, B.-S., RANKIN, D., RENNIE, M.-J and MITTENDORFER, B., 2011. Dietary omega-3 fatty acid supplementation increases the rate of muscle protein synthesis in older adults: a randomized controlled trial. American Journal of Clinical Nutrition, vol. 93, no. 2, pp.402-412.

TER BORG, S., DE GROOT, L.-C.P.G.M., MIJNARENDS, D.-M., DE VRIES, J.-H.M., VERLAAN, S., MEIJBOOM, S., LUIKING, Y.-C. and SCHOLS, J.-M.G.A., 2016. Differences in Nutrient Intake and Biochemical Nutrient Status Between Sarcopenic and Nonsarcopenic Older Adults-Results From the Maastricht Sarcopenia Study. Journal of the American Medical Directors Association, vol. 17, no. 5, pp. 393-401.

TER BORG, S., VERLAAN, S., HEMSWORTH, J., MIJNARENDS, D.-M., SCHOLS, J.-M.G.A., LUIKING, Y.-C. and DE GROOT, L.-C.P.G.M., 2015. Micronutrient intakes and potential inadequacies of community-dwelling older adults: a systematic review. British Journal of Nutrition, vol. 113, no. 08, pp. 1195-1206.

URZI, F., ŠIMUNIČ, B. and BUZAN, E., 2017. Basis for Sarcopenia Screening With the SARC-CalF in Nursing Homes. Journal of the American Medical Directors Association, vol. 18, no. 11, pp.991-e5.

VAN ROSSUM C.-T.M, FRANSEN H.-P, VERKAIK-KLOOSTERMAN J, BUURSMA-RETHANS E.-J.M, OCKE M.-C, 2011. Dutch National Food Consumption Survey 2007-2010: Diet of children and adults aged 7 to 69 years | RIVM. Report Number 350050006/2011. National Institute for Public Health and the Environment, [online]. [viewed 23 August 2021]. Available from: https://rivm.openrepository.com/handle/10029/261553

VELLAS, B., GUIGOZ, Y. GARRY, P.-J., NOURHASHEMI, F., BENNAHUM, D., LAUQUE, S. and ALBAREDE, J.-L., 1999. The mini nutritional as- 
sessment (MNA) and its use in grading the nutritional state of elderly patients. Nutrition, vol. 15, vol. 2, pp.116-122.

VERLAAN, S., MAIER, A.-B., BAUER, J.-M., BAUTMANS, I., BRANDT, K., DONINI, L.-M., MAGGIO, M., MCMURDO, M.-E.T., METS, T., SEAL, C., WIJERS, S.-L.J., SIEBER, C., BOIRIE, Y. and CEDERHOLM, T., 2018. Sufficient levels of 25 -hydroxyvitamin $\mathrm{D}$ and protein intake required to increase muscle mass in sarcopenic older adults - The PROVIDE study. Clinical Nutrition, vol. 37, no. 2, pp.551-557.

VOLKERT, D, BECK, A.-M, CEDERHOLM, T., 2018. ESPEN guideline on clinical nutrition and hydration in geriatrics. Clinical Nutrition, vol. 38 , no. 1 , pp. $10-47$.

WALRAND, S., GUILLET, C., SALLES, J., CANO, N. and BOIRIE, Y., 2011. Physiopathological Mechanism of Sarcopenia. Clinics in Geriatric Medicine, vol. 27 , no. 3, pp. 365-385.

WELCH, A.-A., JENNINGS, A., KELAIDITI, E., SKINNER, J. and STEVES, C.-J., C. J. (2020). Cross-sectional associations between dietary antioxidant vitamins $\mathrm{C}, \mathrm{E}$ and carotenoid intakes and sarcopenic indices in women aged 18-79 years. Calcified tissue international, vol. 106, no. 4, pp. 331-342.

WILSON, M.-M.G. and MORLEY, J.-E., 2003. Invited Review: Aging and energy balance. Journal of Applied Physiology, vol. 95, no. 4, pp. 1728-1736.

WU, P.-Y., HUANG, K.-S., CHEN, K.-M., CHOU, C.-P., TU, Y.-K., 202O. Exercise, nutrition, and combined exercise and nutrition in older adults with sarcopenia: A systematic review and network meta-analysis. Maturitas, [online]. [viewed 23 August 2021]. Available from: https://doi. org/10.1016/j.maturitas.2020.12.009 